\title{
Disarmed principals: institutional resilience and the non-enforcement of delegation
}

\author{
Moritz Weiss ${ }^{*}$ (1) and Tim Heinkelmann-Wild(D) \\ Geschwister-Scholl-Institute of Political Science, Ludwig-Maximilians-Universität München, Munich, Germany \\ ^E-mail: moritz.weiss@gsi.lmu.de
}

(Received 12 December 2019; revised 17 February 2020; accepted 24 March 2020; first published online 06 May 2020)

\begin{abstract}
Governments across the world increasingly rely on non-state agents for managing even the most sensitive tasks that range from running critical infrastructures to protecting citizens. While private agents frequently underperform, governments as principals tend nonetheless not to enforce delegation contracts. Why? We suggest the mechanism of institutional resilience. A preexisting set of rules shapes non-enforcement through the combination of (i) its structural misfit with the delegation contract and (ii) asymmetric interdependence that favors the agent over time. To demonstrate the plausibility of our argument, we trace the political process behind Europe's largest military transport aircraft, the A400M. Governments delegated the development and production of this complex program to a private firm, Airbus. They layered a 'commercial approach' onto traditionally state-run defense industries. Yet, resilience caused these new formal rules to fail and eventually disarmed principals. Our mechanism constitutes an innovative approach by theorizing an alternative path toward dynamic continuity.
\end{abstract}

Keywords: indirect governance; historical institutionalism; delegation; institutional resilience; defense industries; A400M

\section{Introduction}

Governments across the globe increasingly rely on non-state intermediaries even for the most sensitive tasks (Genschel and Zangl, 2014). ${ }^{1}$ Political science research on public-private partnerships has revealed the outsourcing of national security to private companies (Markusen, 2003; Schilde, 2017: 255-262). Similarly, scholarship on the delegation of critical tasks to international organizations (IOs) has shown their increasing authority and intrusiveness (Tallberg, 2002a; Hawkins et al., 2006). Many of such indirect governance arrangements, however, face one key challenge - independent from whether tasks are delegated to profit-oriented firms or IOs (Abbott et al., 2017, 2019). Governments as principals often refrain from strictly enforcing the terms of delegation. ${ }^{2}$ For instance, scholars have stressed the underperformance of the World Health Organization, which is hampered by its regional offices' unchecked powers that 'exceed the constitutional rights granted to them' (Hanrieder, 2016: 97). Yet, this failure has not led to a reinforcement of the initial constitutional rules. Moreover, research on outsourcing shows that credit rating agencies have not only merely underperformed but also contributed to the fiascos of the most recent financial crisis. Yet, governments did neither withdraw regulatory powers from nor

\footnotetext{
${ }^{1}$ The order of author names reflects this paper's initial emergence within a project funded by the German Research Foundation (WE 3653/4-1) rather than both authors' individual - since equal - contribution.

${ }^{2} \mathrm{We}$ adopt an indirect governance perspective and thus use the terms principal when referring to the government, and agent when referring to its non-state contractor.
}

(C) European Consortium for Political Research 2020. This is an Open Access article, distributed under the terms of the Creative Commons Attribution licence (http://creativecommons.org/licenses/by/4.0/), which permits unrestricted re-use, distribution, and reproduction in any medium, provided the original work is properly cited. 
enforce existing contracts with these 'resilient blunderers' (Kruck, 2016). While we thus observe widespread slackness of agents, governments acting as their principals often do not enforce delegation contracts. Why?

We distinguish between two sets of drivers of non-enforcement that political science scholars have identified. Principals may be incapable of enforcing delegation contracts, for example, due to imperfect information about agents as well as collective action problems (Miller, 2005; de Bièvre et al., 2013; Popa, 2018). Principals may also be unwilling to enforce delegation contracts because, for instance, sanctions would erode the agent's competence to accomplish the delegated task (Abbott et al., 2019; Becker, 2019). We suggest, by contrast, a historical-institutionalist explanation for trajectories in which principals, though sometimes able and at other times willing to enforce a delegation contract, eventually refrain from doing so. Therefore, we theorize a mechanism of dynamic continuity, namely institutional resilience (Pierson, 2004: 142-153; Weiss, 2019) that explains the non-enforcement of delegation over time.

Institutional resilience operates under two conditions. First, there is a structural misfit between preexisting and layered rules, that is, 'new elements [crafted] onto an otherwise stable institutional framework' (Thelen, 2004: 32). Principals and agents follow the two sets of rules inconsistently, which gives rise to uncertainty and conflict. Second, there is an asymmetrical power relationship that favors the agent over time. This shapes the eventual resolution of the political conflict between principals and agents over which rules to follow. When agents prefer the preexisting over the layered rules, continuity will prevail. We therefore zoom in on the causal process underlying dynamic continuity as we unpack the conditions under which institutional resilience trumps incremental change through layering (Olsen, 2009; Mahoney and Thelen, 2010; van der Heijden, 2010).

We demonstrate the plausibility of our argument by tracing the political process that led to the non-enforcement of the rules governing the development and production of a military transport aircraft, the A400M program. Arms procurement is one of the governments' core tasks which they regularly contract out to private companies (Popa, 2018) and thus belongs to the so-called commanding heights of the economy (e.g. Weiss, 2020). ${ }^{3}$ The A400M constitutes the largest, as well as most prestigious, collaborative defense project in Europe today (Thiem, 2011). In 2003, Germany, France, Belgium, the United Kingdom, Turkey, and Spain agreed to build a military transport aircraft and contracted its development and production out to EADS/Airbus. ${ }^{4}$ We conceptualize this as delegation from the governments as principals to the firm as an agent (Kurc and Oktay, 2018: 473-475; see also, Moravcsik, 1993: 130-131; Krotz, 2011). The provisions of the delegation relationship were layered onto the preexisting institutions of state-run defense sectors in Europe. A novel 'commercial approach' deviated from the established rules. It guaranteed Airbus significant freedom; at the same time, it provided participant states with fixed prices and delivery schedules (Joana and Smith, 2006). Yet, despite delays and enormous cost overruns, governments abstained from enforcing these 'commercial' terms of delegation. Instead, they returned to the defense sector's original rules of informal coordination. Continuity ultimately prevailed.

\footnotetext{
${ }^{3}$ We understand the commanding heights as private industries essential for the national economy as a whole and, therefore, with a prominent role of the state. Admittedly, arms procurement is an exceptional task since it not only constitutes a core state power (Weiss, 2014) but is also characterized by an idiosyncratic market structure (Bialos et al., 2009). We hold, however, that our case study allows for contingent generalizability. First, arms procurement has gradually lost its exceptional legal nature within the European Union (EU) and beyond. Today, arms acquisitions are much closer to public procurement rules than in the past and a remarkable body of case law is emerging in this domain (Weiss and Blauberger, 2016). Hence, an increasing number of scholars no longer apply theoretical instruments from high politics to the study of defence industries, but engages with standard political science theories (De Vore and Weiss, 2014; Schilde, 2017). Second, we theorize and analyze the implementation of a political decision. The market structure as well as high politics considerations clearly played a role when governments opted for a European - rather than an American - transport aircraft (Joana and Smith, 2006; Faure, 2019). Yet, the following interactions between governments as principals and private firms as agents were no longer predominated by national security interests. Instead, they resembled the logic of governments' manifold practices at the commanding heights.

${ }^{4}$ In the following, we refer to the company's current name: Airbus.
} 
In our analysis, we have opted to focus on the German government as, of all the principals, it was the one most willing and most capable of strictly enforcing the formal provisions. ${ }^{5}$ First, Germany had the strongest interest in applying the new layered rules as it would be most affected by the program's failures. The German version of the A400M faced the most severe technological problems, cost overruns, and delays. In addition, the German government employed powerful reformers after 2014, all of whom agreed to treat the A400M contract as a showcase of change. Second, the country's successful macro-economic performance made it less dependent on jobs at Airbus and its suppliers than other participant governments. Germany was thus 'least likely' to privilege non-enforcement in exchange for jobs (see George and Bennett, 2005: 109-125; Gerring, 2007: 115). This deliberate selection of the most willing and the most capable principal creates a bias toward strict enforcement of the layered rules and thus allows for some contingent generalization of our theoretical argument.

The paper starts by showing that both the opportunities provided to the principal by formal institutions and its preferences would have led us to expect a strict enforcement of the A400M contract. Second, to explain why non-enforcement prevailed nevertheless, we introduce the resilience mechanism and spell out its observable manifestations. Third, we present the findings of our process-tracing analysis. Finally, we discuss the broader theoretical implications beyond explaining why principals accept agents' noncompliance. More generally, our argument about how institutional resilience disarms principals contributes to historical-institutionalist scholarship by providing the micro-foundations of dynamic continuity.

\section{Why enforcement of the contract should have been expected}

We suggest the following conceptualization of whether a delegation contract is enforced, or not (Casper, 2001; Tallberg, 2002b). Principals may approach agents that underperform or slack in one of the two ideal-typical ways: Strict enforcement means that principals and agents implement their contract exclusively in line with the written terms. If interpretations diverge, disputes are settled by third parties (e.g. courts) according to the contractual prescriptions (de Bièvre et al., 2013). Strict enforcement thus has three observable implications: (i) extensive monitoring; (ii) (threat of) sanctions and compensation; and (iii) dispute settlement by third parties. Nonenforcement, by contrast, means that principals adopt a perspective beyond the formal contract and promote informal compromises beyond the written terms. When unforeseen circumstances occur, contracting parties seek mutual accommodation based on socially shared practices rather than dispute settlement by third parties. Non-enforcement thus has three observable implications: (i) emphasis on social norms, such as risk-sharing; (ii) informal agreements beyond the written terms; and (iii) bilateral consensus-finding between governments and firms (Bastings et al., 2017: $300-301)^{6}$

Germany's non-enforcement of the A400M program seems to contradict the theoretical expectations of why principals supposedly decide against enforcing delegation contracts. Indeed, the government was not only able but also willing to enforce the A400M program in accordance with the written terms.

\footnotetext{
${ }^{5}$ Samuel Faure (2019) conducted extensive field research on France's participation in the A400M and provided important insights on the distinct 'configuration' there.

${ }^{6}$ Our distinction between strict enforcement and non-enforcement largely corresponds to the notion of different enforcement styles (Bastings et al., 2017) and is also compatible with the difference between dyadic and triadic enforcement constellations (de Bièvre et al., 2013). Please note that we do not theorize the normative desirability of either enforcement or non-enforcement. Both have distributive consequences and create losers as well as winners. We do not make theoretical assumptions on which better serves public welfare.
} 


\section{Formal institutional opportunities: the capacity for strict enforcement}

Scholars from various research traditions have explained the enforcement of contracts by formal institutions. Both legal scholars and rational choice theorists expect actors to largely follow formal rules (La Porta et al., 1998; Koremenos et al., 2001; see also, Culpepper, 2005: 177-184). Hence, governments should enforce formal prescriptions as agreed with the firm. Given that, from this theoretical perspective, the A400M contract is expected to be the primary source of information, how would the enforcement of formal rules have looked like?

First, due to the firm's high discretion within the development process, the formal rules incentivized purchasing states to monitor Airbus extensively. For instance, governments' direct control of critical milestones was limited as development, certification, and production were integrated into a 'single phase contract' (Mawdsley, 2013; KPMG et al., 2014). Moreover, the 'commercial approach' provided Airbus with significant freedom to choose subcontractors according to a value-for-money logic rather than national origin (Joana and Smith, 2006; Giegerich, 2010: 94). Formal rules thus required governments to monitor Airbus from the outset as the demand for firsthand information increased with the granting of discretionary opportunities (Mawdsley, 2013: 25). They followed the logic of 'eyes on - hands off (Masseret and Gautier, 2009: 21).

Yet, the discretion granted did not lead to careful monitoring. Although governments learned about problems resulting from Airbus' codified discretion, even Germany, which was expected to play hardball with the firm (Senior Airbus Official, 2016), hardly monitored it. For instance, the German Ministry of Defense discovered as early as 2007 that Airbus was exploiting its freedom within the 'functional requirements' to develop the cheapest solutions (Der Spiegel, 2015a). Furthermore, Airbus only revealed difficulties, such as the software problems of the engine supplier, 'piece by piece' (Lange, 2009: 2). Nevertheless, the only attempt at systematic monitoring took place in 2009 when governments selected PricewaterhouseCoopers to conduct an external audit of Airbus (Dickow, 2010: 2; Hepher and Siebold, 2010). Hence, the formally granted discretion did not translate into generally increased monitoring. The governments failed to adjust their behavior to the new formal rules.

Second, the A400M contract prescribed legal responsibilities and opportunities for compensation claims as well as sanctions. According to the legal approach, these should have informed how contracting parties resolved conflicts. Yet, when disagreements between the governments and Airbus occurred, this tended to result in the re-establishment of informal consensus rather than sanctions. In late 2009, the company demanded concessions from purchasing states even after the external audit revealed its noncompliance with the contract, including delays and cost overruns (Dickow, 2010: 2; Hepher and Siebold, 2010). Nevertheless, Germany refrained from making use of its contractual rights which obliged Airbus to absorb the risk of cost overruns and to compensate for delays (Lange, 2009: 3). Governments also had the right to withdraw from the project collecting a refund of 5.4 billion euros. However, Germany neither enforced the contract nor used the threat to withdraw, but weakened its own position by publicly announcing its interest in continuing the A400M program (Der Spiegel, 2009a; New York Times, 2009; FAZ, 2010a). The conflict was resolved by a mutual agreement on risk-sharing that accommodated Airbus far beyond contractual prescriptions (FAZ, 2010c; Giegerich, 2010: 93; Hepher and Siebold, 2010).

In a nutshell, a legal approach would have expected enforcement in line with the A400M contract. Yet, Germany and the other governments refrained from exploiting their institutional opportunities to enforce the contract. They did neither thoroughly monitor whether Airbus completed delegated tasks nor did they threaten sanctions or claim compensation.

\section{Actors' preferences: the willingness to insist on strict enforcement}

It remains conceivable that non-enforcement is driven by what governments want and not so much by what they are legally supposed to do. Given stable institutions, a changed order and 
intensity of preferences might explain (non-)enforcement (Moravcsik, 1993; Scharpf, 1997: 5168). Most significantly, protracted procurement processes often empower new actors during the implementation phase who did not participate in the initial agreement (e.g. Krotz, 2011; Mahoney and Thelen, 2010: 22-28). ${ }^{7}$ The latter can either promote new policy objectives or reinforce the former ones (Pierson, 2004: 120; Mahoney and Thelen, 2010: 22-29; see also, Wagner et al., 2018). This would lead us to expect the enforcement of the A400M contract when new actors with a clear preference for this substantive policy were empowered.

In fact, when Ursula von der Leyen assumed the office of Minister of Defense in 2014, she persistently pushed forward far-reaching reforms of the German defense sector in response to several procurement fiascos. Most notably, she brought in private consultants who aimed at substantially improving risk management as well as control in armament programs. A report by KPMG of September 2014 was an 'eye-opener' (Scherf, 2017): all existing contracts prescribed a risk distribution that was to the clear disadvantage of government - with one exception: the A400M contract. KPMG thus suggested sending an unambiguous signal by its strict enforcement (FAZ, 2014; KPMG et al., 2014: 13-15).

Now, this course of action was not only enabled by formal rules, but the political willingness, even eagerness, to pursue it, was clear. The newly appointed armaments director and former consultant Gundbert Scherf even stressed that the A400M contract should become the reform's 'flagship' (Scherf, 2017). This empowerment of new actors with clear preferences for change could have explained a dynamic of Germany demanding compensation for delays and capacity deficits (FAZ, 2014; Der Spiegel, 2015a) as well as its initial reluctance to accept Airbus' demands for renegotiation in 2015 (Financial Times, 2015; Der Spiegel, 2016b; Senior Airbus official, 2016). Yet, this momentum rapidly vanished. Even though Germany was clearly willing to enforce the contract from 2014, non-enforcement ultimately prevailed.

In sum, we face a theoretical puzzle: neither the principal's preferences nor the opportunities provided by formal institutions suggest the observed non-enforcement of the tasks delegated to Airbus.

\section{Historical institutionalism and the non-enforcement of delegation contracts}

To explain non-enforcement of delegation contracts, we suggest institutional resilience as a mechanism that reproduces the underlying patterns of how actors behaved historically. Layering initially seeks to induce incremental change, but resilience steps in and gives rise to continuity in a dynamic way. As a result, layered rules have led to instability; yet, outcomes eventually resembled the past. In other words, resilience constrains the effectiveness of new rules by reproducing preexisting rules. Building on historical institutionalism, the following section theorizes this mechanism and, then, spells out observable manifestations to probe its operation within the trajectory of the A400M program in the empirical analysis.

\section{Theorizing the institutional resilience mechanism}

We start out from the historical-institutionalist notion that initial institutional choices may - over time - self-reinforce and thus increase the likelihood of actors following preexisting rules (Krotz, 2011; Mahoney and Thelen, 2010; Rixen and Viola, 2014). Institutional resilience denotes the reproduction of the underlying patterns of behavior and thus the basic rules within a given

\footnotetext{
${ }^{7}$ While new actors, such as policy entrepreneurs, might constructively utilize ambiguity in the agenda-setting phase (Edler and James, 2015), our argument relates to those new actors that interfere in distributive conflicts during the implementation phase.
} 
institutional setting (Pierson, 2004: 142-153; see also, Weiss, 2019). The resilience mechanism ${ }^{8}$ operates under two conditions: (i) a structural misfit between layered and preexisting rules and (ii) asymmetric interdependence in favor of the agent.

First, the structural misfit condition stresses non-complementarity between preexisting rules and new formal rules that have been layered onto them (Hall and Soskice, 2001; Helmke and Levitsky, 2004; Pierson, 2004: 136-162; Büthe and Mattli, 2011: 38-59). National political economies involve 'institutional spheres that function better the more they "complement" one another' (Streeck, 2010: 26). If complementarity is high, neither preexisting institutions nor the new rules are challenged so that institutional contexts operate smoothly. The principals' enforcement is expected to follow an unified set of rules. By contrast, if new rules misfit and thus compete, both the preexisting and the layered rules constitute a conceivable basis for action: principals might, for instance, follow preexisting rules, which implies non-enforcement of the layered rules, and vice versa. Given this ambivalence, the structural misfit condition causes political conflict over which rules to follow. It is this dynamic that transforms a structural condition into opportunities and constraints, upon which actors draw to pursue their preferences.

Second, the condition of asymmetric interdependence in favor of the agent shapes the distribution of bargaining power and thus the resolution of the political conflict (Farrell and Newman, 2016; Moe, 2019). We draw on an issue-specific and dynamic notion of bargaining power: actors' preference intensity determines their costs of nonagreement and thus their willingness to make concessions (Scharpf, 1997; Moravcsik, 1999). Given diverging preferences, asymmetrical information, and the resulting different outside alternatives, principals and agents place different values on finding an agreement. The more one prefers an agreement, the less powerful one is and thus the more willing to make concessions.

We assume that agents tend to prefer the rules of the delegation contract less than principals, since they were in a relative less powerful position at the beginning of the relationship (Abbott et al., 2016, 2019). We further argue that agents will be increasingly empowered over time. The more protracted a delegation relationship, the more informational advantages accrue to agents and the more alternative options they can draw on (Pollack, 1997: 108; De Vore, 2011; see also, Kurc and Oktay, 2018). Agents gain better knowledge of different courses of action, which allows them to create outside options and thus to transform their vulnerabilities into mere sensitivities (Keohane and Nye, 2011). They can also build up capabilities that make them more competent in accomplishing the delegated tasks while rendering alternative agents less attractive for principals (Abbott et al., 2019). As the costs of their nonagreement decrease over time, agents will be increasingly able to impose their preferred rules on principals.

Up to this point, we have suggested that the non-enforcement of a delegation contract depends on two conditions: a structural misfit shaping a conflict and an agent increasingly empowered by asymmetrical interdependence and willing to resist formal enforcement. How are these conditions transposed into micro-level behavior?

The resilience mechanism starts out from the signing of a contract in which a principal delegates tasks to an agent. The trigger is a new formal rule that is layered on a preexisting institutional setting. The contractual prescriptions provide information and structure actors' expectations and behavior. Yet, under the condition of structural misfit, preexisting informal rules suggest a deviating course of action and thus non-enforcement. Principals and agents draw on both of these contradictory opportunities and constraints, which leads to uncertainty about which rules to apply. Hence, they follow preexisting and layered rules inconsistently and shift between the two. This gives rise to contradictory expectations that leave principals and agents dissatisfied. Instability prevails.

\footnotetext{
${ }^{8} \mathrm{~A}$ mechanism can be understood as 'a system that produces an outcome through the interaction of a series of parts [... ]. Each part is composed of entities that engage in activities.' (Beach and Pedersen, 2013: 39)
} 
Given diverging preferences, principals and agents enter distributive conflict that can only be resolved by power bargaining. They exchange threats and promises in order to move the other toward their own preference order. While this divergence leads to conflict, it is the distribution of preference intensity that shapes the bargaining outcome. The condition of increasing asymmetrical interdependence in favor of the agent entails the latter assigning less value to the resolution of the distributive conflict than the principal does. It thus provides agents with better outside options over time. This empowers them to resist principals' attempts to enforce the layered rules and impose their own preference order. The outcome is non-enforcement of the delegation contract. Figure 1 summarizes the operation of the institutional resilience mechanism.

\section{Tracing the operation of the institutional resilience mechanism}

This section spells out how the resilience mechanism operates in collaborative arms programs, such as the A400M. First, armament projects are based on formal contracts between governments (i.e. principals) and firms (i.e. agents) that implement them (Moravcsik, 1993). The structure and the content of this contract suggest specific patterns of enforcement. For instance, the development of a new military platform may be separated from the production phase; alternatively, development and production may be integrated into a single process. While separation automatically guarantees phase-by-phase control, integration requires permanent monitoring across the whole process since regular control has been abandoned.

Second, the structural misfit condition implies observing contradictory and increasingly conflictual behavior of governments and firms. They are uncertain over whether to act in accordance with the layered rules or with preexisting informal rules and historical legacies (e.g. De Vore and Weiss, 2014; see also, Allen et al., 2007). ${ }^{9}$ Hence, the question arises of which set of competing rules will prevail. The effectiveness of rules depends on actors' beliefs, which, in turn, impact upon observable behavior (Helmke and Levitsky, 2004: 728). Great disparity between the rules' effectiveness will lead to the effective rule replacing the ineffective one. By contrast, if both sets of competing rules are effective, governments and firms are uncertain and apply them inconsistently. For instance, informal agreements on some issues will be combined with formal monitoring and sanctions.

Third, the condition of asymmetrical interdependence in favor of the agent implies observing not only the diverging interests of governments and firms (i.e. what they each want) but also a different degree of preference intensity (i.e. how much they want it). Both can be assessed by applying theories, using documents, and asking experts (Zürn, 1997: 298-302). We expect contracting partners to engage in power bargaining and to apply strategies of threats and promises that allow for outcomes close to their preferences. The initial contract is supposedly closer to the principal's preferences as more than one agent is normally available for the delegated task. Over time, however, the firm should be able to demonstrate more resolve; its threats should become increasingly credible and thus effective. By contrast, governments' alternative options weaken over the duration of the procurement project. They will thus be willing to grant concessions to bring the arms program to a successful conclusion. This disparity in the costs of nonagreement will rise over the duration of a protracted process as governments will incrementally withdraw from - or lose outside options.

Finally, we expect the outcome to be closer in line with the preferences of the agent. This implies that institutional resilience has empowered the agent to resist the layered rules that were put forward by the government. The delegation contract is not enforced; resilience has prevailed.

\footnotetext{
${ }^{9}$ Our premise is that actors opportunistically follow rules to satisfy their interests. The unfolding uncertainty is thus not only a pure coordination problem, but one with distributive consequences that actors are supposedly aware of. In other words, both principals and agents are regularly involved in venue or forum shopping (e.g. Coen et al., 2019). We are highly grateful to one of our reviewers for helping us to clarify this point.
} 


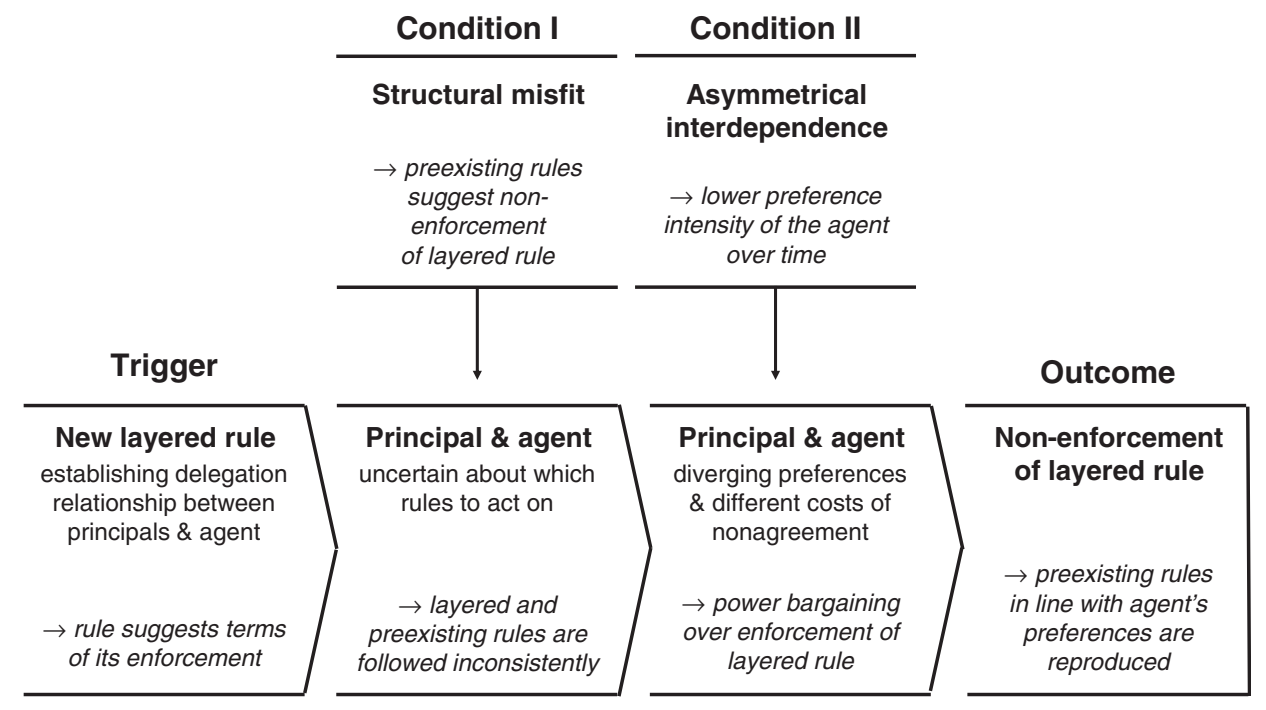

Figure 1. Institutional resilience mechanism.

\section{The operation of institutional resilience in the A400M program}

To probe the workings of the institutional resilience mechanism in the case of the A400M program, we employ process-tracing (Beach and Pedersen, 2013). Our empirical evidence stems from a diversity of sources, which are triangulated to trace the causal process: (i) official documents, secondary literature, and think tank approaches; (ii) the complete media coverage by Frankfurter Allgemeine Zeitung, Die Zeit, Der Spiegel, Financial Times, and New York Times from 1995 through 2018; and (iii) semi-structured interviews with governmental and corporate protagonists (e.g. former CEOs, A400M program managers, armaments directors). Our objective is to develop within-case inferences about the operation of the resilience mechanism, which can be generalized to further instances of delegation.

\section{Layering new rules of defense procurement}

The A400M contract was layered onto the preexisting institutions of state-run defense sectors in Germany. Its novel 'commercial approach' prescribed legal responsibilities and opportunities for compensation claims as well as sanctions. It guaranteed Airbus the number of aircraft orders and significant freedom in choosing capable (rather than politically opportune) subcontractors, while participant states could postpone initial development funding and rely on a fixed price (Lange, 2009).

By contrast, Germany's historically evolved approach to defense procurement was rather guided by informal rules (Weiss, 2020). The specific design of formal delegation contracts normally allowed for the complementary effectiveness of the informal setting. Strictly contractual coordination was thus subordinated (Creswell and Kollmer, 2013). Traditionally, research and development were separated from production. The former phases would begin with proof of concept studies and gradually evolved toward technology demonstrators. Governments and firms concluded a myriad of minor contracts within this process and constantly negotiated the precise terms. As a result, public-private interactions strived for political compromises within a loose and informal framework of rules. One knew the other, relied on flexible exchanges, and engaged in mutual risk-sharing. This involved diffuse reciprocity among principals and agents, rather than an adversarial 'tit-for-tat' (Scherf, 2017). Formal delegation contracts thus largely suggested the 
flexible enforcement of arms programs. For instance, the German government relied on informal coordination to establish political compromises with firms in the Eurofighter program and its predecessors (De Vore, 2014: 436). Even though preferences sometimes diverged, contract parties repeatedly found a consensus, whereby the written terms were flexibly interpreted.

\section{From structural misfit toward uncertainty and conflict}

As the German government acted according to both the layered contract as well as preexisting institutions from 2003 to 2013, uncertainty grew. Sometimes, both rules were simultaneously effective (i.e. competition between new and preexisting rules). At other times, only informal rules were effective (i.e. the contract was substituted by the preexisting rules).

First, the conclusion of the 2003 contract itself indicated a shared belief in the prevalence of informal rules of diffuse reciprocity. Governments politically intervened in contradiction to the contractual 'commercial approach' principle (Joana and Smith, 2006: 78-79; Dickow, 2010: 2; Scherf, 2017), when the development of the engine was awarded to Europrop International (EPI). While Airbus initially preferred the Canadian firm, Pratt \& Whitney, governments pressed for EPI to save jobs and technical knowledge in Europe (Lange, 2009: 2; Giegerich, 2010: 93; Senior Airbus official, 2016). ${ }^{10}$ The agent not only accepted this political interference but also remained legally responsible for the functioning of the engines (FAZ, 2010a; Mawdsley, 2013: 27; Financial Times, 2015). This shows Airbus' strong belief that enforcement would follow established informal institutions rather than an adversarial 'tit-for-tat' that layered rules suggested. Based on previous experiences, the firm abstained from modifying the written terms of the delegation contract and expected to later renegotiate and demand concessions (Die Zeit, 2010; Scherf, 2017). Hence, preexisting beliefs about how (not) to enforce collaborative arms programs were effective at the time of contracting. If that was not the case, Airbus' signature of the 2003 contract would have been beyond any conceivable rationality.

Second, Airbus attempted to exploit the opportunities provided by both sets of rules. On the one hand, the agent, in accordance with preexisting rules, pressed for concessions from principals. From 2007 to 2009, the A400M project suffered from delays, cost overruns, and technical problems. However, Airbus demanded fairness and burden sharing in the light of prior political interferences, that is, a new delivery plan and a waiver for delays, a reduction in requirements, as well as a reallocation of risk and additional payments (FAZ, 2010b; Hepher and Siebold, 2010). On the other hand, the agent simultaneously referred to the new formal rules and exploited the reduced extent of control instruments provided by the single-phase contract. For example, Airbus relocated engineers from the A400M to the civilian A380 program since the former contract did not ensure that these were permanently available for the military transport aircraft (Mawdsley, 2013: 25; KPMG et al., 2014: 13). Germany's government representatives were increasingly irritated by Airbus' behavior, which, in turn, destabilized mutual expectations (Der Spiegel, 2009b; Lange, 2009: 2). In other words, the agent opportunistically applied both layered and preexisting rules and thus drove uncertainty about the effective rules of the game.

Third, uncertainty strongly materialized in 2009 when both formal and informal rules were simultaneously effective. By March 31, the contract's termination was unilaterally possible given the nonachievement of a critical milestone: the A400M's maiden flight. In case of termination, the agent would have had to refund 5.4 billion euros within 60 days (Der Spiegel, 2009a; Lange, 2009: 3). When Great Britain threatened to take advantage of this contractual opportunity, other governments and Airbus engaged in finding a viable compromise. In an informal 'side letter', Great Britain was allowed to trim its order without claiming a refund (New York Times, 2009; Hepher and Siebold, 2010). At the same time, governments established a monitoring instrument:

\footnotetext{
${ }^{10}$ EPI was composed of Snecma (France), Rolls-Royce (Great Britain), MTU Aero Engines (Germany), and Industria de Turbo Propulsores (Spain).
} 
the detailed audit of Airbus by PricewaterhouseCoopers (Dickow, 2010: 2; Hepher and Siebold, 2010). The resulting report ultimately revealed the agent's management failures and drew the conclusion that Airbus was able to bear the additional costs alone. This provoked a harsh reaction by the firm. Given an imminent rating downgrade due to the report, Airbus claimed that PricewaterhouseCoopers had recalled their assessment - a statement PricewaterhouseCoopers as well as the German Ministry of Defense refused to comment on. Furthermore, a company official reportedly stated that 'it can't be that the German government is now achieving what Boeing has been trying to do for forty years: to bring Airbus down. ${ }^{11}$ This tinkering between the two sets of rules further increased uncertainty, whereby the conflict increasingly escalated.

Finally, preexisting rules ultimately substituted the strict enforcement of the initial contract in late 2009 and early 2010, when the German government deliberately refrained from enforcing its formal rights. The A400M contract not only stipulated a fixed price but also obliged Airbus to bear the risk of cost overruns and to pay damages in case of delays as well as a refund in case of termination (Der Spiegel, 2009a). At this stage, Germany alone would have thus been entitled to 500 million euros in compensation (Lange, 2009: 3). Yet, the government did not invoke the termination clause as a threat, but publicly claimed its interest in the future of the A400M program and repeatedly postponed the termination date (Der Spiegel, 2009a; New York Times, 2009; FAZ, 2010a).

While layered rules would have clearly been more favorable, the principal followed a consensual approach that stressed reciprocity. A compromise was found by March 2010 that should stabilize the program for the following 3 years. Whereas the principals transferred 3.5 billion euros and renounced penalties, the agent took losses of around 4.2 billion euros and introduced cost-cutting measures of 3.6 billion euros. The number of aircraft was reduced, capabilities were canceled or postponed, and deliveries were newly scheduled (FAZ, 2010c; Giegerich, 2010: 93; KPMG et al., 2014). The unit price increased from 124 to 175 million euros (Der Spiegel, 2015a). What is important to note is that, from 2003 through 2013, the German government was unilaterally capable, but unwilling to strictly enforce its delegation contract.

\section{From power bargaining toward the resolution of the political conflict}

There was widespread uncertainty over which rules to follow, when new delays of the A400M gave rise to an open conflict between the German government and Airbus. Since 2014, we thus see what we dubbed change actors consolidating their power within the government. Scholars of institutional change would characterize them as either insurrectionaries or subversives (Mahoney and Thelen, 2010: 23-26) that sought to transform Germany's defense procurement system. Airbus continued to promote an informal solution and asked for renegotiations of the scheduling (Der Spiegel, 2015a; Financial Times, 2015). Yet, the government's change actors enforced the contract and demanded compensation (FAZ, 2017a). The armaments secretary of state, Katrin Suder, proclaimed a 'loss of trust' ${ }^{12}$ in the agent and the German Ministry of Defense publicly stressed 'that the delays are the sole responsibility of the industry.' ${ }^{\text {'1 }}$

This conflict between the principal and the agent intensified as interests gradually diverged. The government was increasingly willing to push forward strict enforcement of formal rules to ensure its military capabilities (Reuters, 2018). It insisted on its contractually guaranteed claims and repeatedly demanded compensation for delays and capability shortfalls (Der Spiegel, 2016a; Senior Airbus official, 2016). By contrast, Airbus stressed informal consensus-finding and, thus, non-enforcement. The agent argued that the A400M program had been based on infeasible schedules and budgets. It therefore demanded a 'fair risk-sharing between customers and industry.'14

\footnotetext{
${ }^{11}$ Unnamed company official, cited by Löwenstein and Schubert (2010: 2); authors' translation.

${ }^{12}$ Katrin Suder, German State Secretary of Defence, cited by Der Spiegel (2015b); authors' translation.

${ }^{13}$ Risk report on the A400M by experts in the German Defence Ministry, cited by Der Spiegel (2015c); authors' translation.
} 
The firm's goal was to limit costs by an informal agreement and to extend the delivery schedule without further penalties (Der Spiegel, 2018; FAZ, 2018b; UK Ministry of Defence, 2018).

From 2017 to early 2018, the government and Airbus attempted to resolve the conflict by the exchange of threats and promises with respect to additional payments and compensation (FAZ, 2017c). While the principal withheld payments due to delays and capability deficits (Schubert and Friese, 2017), the agent was concerned that future compensation would have a severe impact on its cash flow (Köhn, 2017). Airbus alarmingly called to its employees for 'drastic' cost-cutting measures and froze all investments in its defense business (Schubert and Friese, 2017). It claimed that particularly Germany withholding payments 'continued to weigh heavily on cash flow' ${ }^{15}$ and that it was incapable of continuing the project without concessions (FAZ, 2018a).

The outcome of this bargain was shaped by Airbus' and Germany's costs of nonagreement. The agent's preference intensity evolved to become lower than the principal's as the firm depended less on the resolution of the conflict and thus had lower costs of nonagreement. This disparity of costs of nonagreement had grown over time. Back in 2003, the A400M was a window of opportunity for Airbus to enter the market for large transport aircraft. It thus had a high preference intensity. Now, the firm indirectly signaled the 'nuclear option' of completely withdrawing from the project. Although this would have created a dramatic financial (and reputational) loss, it would have put an end to uncertain future scenarios of the A400M and thus Airbus as a whole. This permanent rise of uncertainty had increasingly evolved as a problem at international stock markets since it deteriorated the ratio between potential profits compared to the costs (Hepher and Siebold, 2010; Löwenstein and Schubert, 2010). Write-offs accelerated from 4 billion euros in 2014 up to 7 billion euros in 2017. By actively preparing its exit from the project, the firm threatened the government. This was further reinforced by a public statement that predicted profits from exporting the A400M had vanished anyway (Der Spiegel, 2016b; Financial Times, 2017). In other words, the agent had clearly remained sensitive with respect to the A400M, but it could gradually abolish its initial vulnerability by developing options beyond this specific contract.

By contrast, the principal had moved into the opposite direction. It had experienced an increasingly intense preference for successfully concluding the A400M program, while its initial costs of nonagreement were moderate. On the one hand, the transport aircraft promised vital security benefits. The Bundeswehr was in urgent need of air transport capabilities as the outdated Transall fell short with regard to payload and range (Der Spiegel, 2018). The A400M also promised some autonomy from the United States and Russia (Giegerich, 2010: 93; Mawdsley, 2013: 21-22). This interest had been increasing when Germany promoted a more active role in global security from 2015 (Der Spiegel, 2015a; Scherf, 2017), and this was particularly intensifying by the rising uncertainty about the transatlantic commitment of the Trump administration since 2017 (Farrell, 2017; Shalal, 2018). On the other hand, the A400M program generated long-term knowhow for the European aircraft industry and guaranteed 6000 jobs. After the initiation of series production, the number of German employees had nearly doubled to 10,000 from 2013 onward (Giegerich, 2010: 93; Der Spiegel, 2015a). The principal's projected gains from, and thus interest in, the A400M had critically risen over time and thus decreased its bargaining power.

Given that the government's outside options were shrinking, its costs of nonagreement were rising. First, the extension of the Transall until 2021 was supposed to cost 300 million euros (Der Spiegel, 2015c). Second, although Germany and France decided to build up a joint fleet of eight American Hercules transport aircraft in 2016, this only marginally helped, while it involved costs of 1 billion euros. Most crucially, it reinforced dependence on US goodwill (Seliger, 2017; Wiegel, 2017). Third, another alternative vanished in 2018, when the Russian company Volga-Dnepr did not extend a treaty with North Atlantic Treaty Organization (NATO) countries on leasing 12

\footnotetext{
${ }^{14}$ Tom Enders, CEO of Airbus, cited by FAZ (2017b); authors' translation; see also, Der Spiegel (2016b), Financial Times (2015).

${ }^{15}$ Airbus, cited by Schubert and Friese (2017); authors' translation.
} 
Antonow transporters as a response to sanctions against Russia (FAZ, 2018c). The government increasingly had weak alternative options, its vulnerability was rising, and it was more willing to grant concessions. In return, Airbus could credibly demonstrate resolve and used its superior bargaining position to resist the strict enforcement of the layered rules. From 2014 to 2018, the German government was consequently willing to enforce the delegation contract, but meanwhile incapable to do so.

\section{The eventual non-enforcement of the layered rule}

The ultimate outcome of the power bargain was not to enforce the formal contract according to the written terms. By February 2018, purchasing governments and Airbus informally agreed to extend the delivery schedule and revise penalties (OCCAR, 2018; Reuters, 2018), whereby the Bundeswehr will receive its last A400M in 2026 rather than in 2020 (Der Spiegel, 2018). Airbus' CEO, Tom Enders, publicly expressed his satisfaction as 'the remaining program risks will be significantly reduced.' ${ }^{\prime 6}$

Airbus' stronger bargaining position was based on its credible exit threat, to which the government had eventually to yield: 'the ministry sees it as a big step forward that Airbus fully supports the A400M program with the declaration of intent and that the Bundeswehr can thus be confident that it will actually be able to maintain the aircraft with the required capabilities. ${ }^{17}$ Observers confirmed that 'governments now visibly approach the manufacturer because they do not want to forego the military transporter' (Schubert, 2018). The government eventually turned back to preexisting institutions by engaging in risk-sharing, coordinating via informal agreements, and accommodating Airbus' interests far beyond the prescriptions of the contract. Resilience prevailed.

\section{Conclusion}

This paper addressed why principals refrain from enforcing delegation contracts when agents do not comply. We suggested an institutional resilience mechanism that constrains the effectiveness of layered rules by reproducing preexisting rules (see also, Weiss, 2019). It operates under two conditions. First, a structural misfit between the layered and the preexisting rules leads to uncertainty and thus to inconsistent interactions between principals and agents. Second, the outcome of the resulting political conflict over which rules to follow depends on interdependence. Asymmetrical power relations favor agents over time as they can turn vulnerabilities into sensitivities and thus gradually reduce the costs of nonagreement.

Our empirical analysis of the A400M program demonstrated the operation of the resilience mechanism at the commanding heights of the economy. Even Germany, the most willing and capable principal, did not enforce the delegation contract despite underperformance and agency slack on the part of Airbus. First, the layered rules did not fit with the preexisting institutions of Germany's defense sector, which would have suggested informal consensus-finding. Both the government and the firm drew on these competing opportunities and constraints. The parallel effectiveness of the new formal rules and the preexisting institutions increased uncertainty about which rules to follow. Without this misfit and the unfolding uncertainty, the resilience mechanism would have hardly begun to operate. This conflict accelerated when change actors were empowered in the German government. The latter pushed for the strict enforcement of the contract, whereas Airbus insisted on risk-sharing and an informal consensus. Both parties engaged in power bargaining and exchanged threats as well as promises. Second, asymmetric interdependence increasingly favored the agent, for whom the costs of nonagreement had decreased. By contrast,

\footnotetext{
${ }^{16}$ Tom Enders, CEO of Airbus, cited by FAZ (2018b); authors' translation.

${ }^{17}$ Press release of the German government, cited by Reuters (2018).
} 
the principal's preference intensity for advancing the A400M program gradually increased. The resulting bargaining outcome was thus closer to Airbus' interests and clearly deviated from the layered rules. In other words, preexisting rules prevailed, and the delegation contract was not enforced.

General inferences from single case studies necessarily remain limited. First, we cannot automatically conclude that the mechanism travels to cases of delegation to IOs since our empirical focus was on delegation to a profit-oriented private firm. A second caveat pertains to the nature of the defense sector and its distinct market structure. However, we hold that this context is not as unique as one might think but comparable to other public-private delegation relationships within the commanding heights of national economies (De Vore and Weiss, 2014; Schilde, 2017; Weiss, 2020). Moreover, while the market structure as well as high politics considerations might play a dominant role at the initiation of a delegation relationship, our theory relates to the implementation of a political decision and its enforcement. Future research should thus look into cases beyond the commanding heights of the economy and profit-oriented agents. We particularly expect to observe the coincidence of the two conditions that give rise to our mechanism in cases of attempted structural reforms of economic sectors (Moe, 2019). While our resilience mechanism is thus not universally applicable to all cases of public contracting, it might be generalizable to many salient instances.

Our paper contributes to wider scholarship on indirect governance (Tallberg, 2002a; Hawkins et al., 2006; Büthe and Mattli, 2011; Abbott et al., 2017; Weiss and Jankauskas, 2019), particularly to research on why principals tolerate agents' noncompliance with a delegation contract (Miller, 2005; de Bièvre et al., 2013; Kruck, 2016; Slayton and Clark-Ginsberg, 2018; Abbott et al., 2019). In addition, our argument on how the combination of institutional misfit and asymmetric interdependence produces resilience yields two broader contributions to historical-institutionalist theorizing.

First, our study helps to specify the conditions under which institutional resilience prevails over incremental change via layering (Mahoney and Thelen, 2010; van der Heijden, 2010). The new rules of the A400M contract were not only added to the preexisting institutional setting but were even fostered by a powerful coalition of change actors within the German government. Exploring a negative instance of layering thus allows us to point out its highly demanding prerequisites: incremental change through layering is inhibited when structural misfit combines with asymmetrical interdependence favoring defenders of the status quo. Under these conditions, institutional resilience trumps layering.

Second, historical-institutionalist scholarship, in general, stresses continuity in the form of path dependence. The longer an institutional setting has existed, the more functional complementarities evolve, the stronger positive feedbacks become, and the more increasing returns on investments are yielded (Pierson, 2000; Rixen and Viola, 2014). While these behavioral mechanisms of dynamic continuity have been constitutive for the research program, the historical-institutionalist agenda has increasingly turned toward incremental change through, for instance, mechanisms of layering, reactive sequences, or conversion. These approaches have, in particular, emphasized agency and power politics (Olsen, 2009; Mahoney and Thelen, 2010; van der Heijden, 2010; Schilde, 2017; Moe, 2019). Our theoretical innovation lies in combining both strands. We have introduced institutional resilience as a behavioral mechanism that tends to reproduce dynamic continuity, but, at the same time, we have integrated power politics that is central to scholarship on incremental change. Given uncertainty and conflict evoked by a structural misfit, it is the costs of nonagreement - rather than positive feedback or increasing returns - that drive continuity and prevent incremental change.

Acknowledgment. The authors would like to thank our three anonymous reviewers, the editors, as well as the participants of the research colloquium at Ludwig-Maximilians-Universität (LMU) Munich and the 5th Conference of the 'International Relations Section' of the German Association for Political Science (DVPW), October 2017, Bremen, for their constructive 
comments. The authors are especially grateful to Felix Biermann, Orfeo Fioretos, Ulrich Krotz, Andreas Kruck, Berthold Rittberger, Frank Sauer and Bernhard Zangl. We would also like to thank Kellie Jones, Louisa Klein-Bölting, and Matthias Kappler for excellent research assistance. This research would not have been possible without the appreciated funding provided by the German Research Foundation (WE 3653/4-1) and by the Robert Schuman Centre for Advanced Studies (RSCAS) of the European University Institute in Florence.

\section{References}

Abbott, K.W., P. Genschel, D. Snidal and B. Zangl (2016), 'Two logics of indirect governance: delegation and orchestration', British Journal of Political Science 46(4): 719-729.

Abbott, K.W., P. Genschel, D. Snidal and B. Zangl (2019), 'Competence versus control: the governor's dilemma', Regulation and Governance Early View: 1-18.

Abbott, K.W., D. Levi-Faur and D. Snidal (2017), 'Theorizing regulatory intermediaries: the RIT model', The ANNALS of the American Academy of Political and Social Science 670(1): 14-35.

Allen, J., A.D. James and P. Gamlen (2007), 'Formal versus informal knowledge networks in R\&D: a case study using social network analysis', RङD Management 37(3): 179-196.

Bastings, L., E. Mastenbroek and E. Versluis (2017), 'The other face of Eurolegalism: the multifaceted convergence of national enforcement styles', Regulation \& Governance 11(3): 299-314.

Beach, D. and R.B. Pedersen (2013), Process-Tracing Methods: Foundations and Guidelines, Ann Arbor: University of Michigan Press.

Becker, M. (2019), 'When public principals give up control over private agents: the new independence of ICANN in internet governance', Regulation \& Governance 13(4): 561-576.

Bialos, J.P., C.E. Fisher and S.L. Koehl (2009), Fortresses and Icebergs: The Evolution of the Transatlantic Defense Market and the Implications for U.S. National Security Policy. Washington, DC: Center for Transatlantic Relations.

Büthe, T. and W. Mattli (2011), New Global Rulers: The Privatization of Regulation in the World Economy, Princeton, New Jersey: Princeton University Press.

Casper, S. (2001), 'The legal framework for corporate governance: the influence of contract law on corporate strategies in Germany and the United States', in P.A. Hall and D.W. Soskice (eds.), Varieties of Capitalism: The Institutional Foundations of Comparative Advantage, Oxford, New York: Oxford University Press, pp. 387-416.

Coen, D., M. Guidi, N. Yordanova and A. Héritier (2019), 'The logic of regulatory venue shopping: a firm's perspective', Public Policy and Administration.

Creswell, M.H. and D.H. Kollmer (2013), 'Power, preferences, or ideas? Explaining West Germany's armaments strategy, 1955-1972', Journal of Cold War Studies 15(4): 55-103.

Culpepper, P.D. (2005), 'Institutional change in contemporary capitalism: coordinated financial systems since 1990', World Politics 57(2): 173-199.

de Bièvre, D., A. Poletti and L. Thomann (2013), 'To enforce or not to enforce? Judicialization, venue shopping, and global regulatory harmonization', Regulation \& Governance 8(3): 269-286.

De Vore, M.R. (2011), 'The arms collaboration dilemma: between principal-agent dynamics and collective action problems', Security Studies 20(4): 624-662.

De Vore, M.R. (2014), 'International armaments collaboration and the limits of reform', Defence and Peace Economics 25(4): 415-443.

De Vore, M.R. and M. Weiss (2014), 'Who's in the cockpit? The political economy of collaborative aircraft decisions', Review of International Political Economy 21(2): 497-533.

Der Spiegel (2009a), 'Airbus droht Kündigung', Der Spiegel, March 2nd, p. 17.

Der Spiegel (2009b), 'Mängel an der Heckflosse', Der Spiegel, August 3rd, p. 28.

Der Spiegel (2015a), 'Zu fett zum Fliegen', Der Spiegel, January 24th, p. 16.

Der Spiegel (2015b), 'Kein Geld für Airbus', Der Spiegel, February 21st, p. 17. February

Der Spiegel (2015c), 'Melden macht frei', Der Spiegel, August 8th, p. 29.

Der Spiegel (2016a), 'Schadensersatz für Pannen-Airbus', Der Spiegel, November 19th, p. 29.

Der Spiegel (2016b), 'Verschwende nie eine Krise', Der Spiegel, December 17th, p. 64.

Der Spiegel (2018), 'Flügellahmer Transportflieger', Der Spiegel. February 17th, p. 34.

Dickow, M. (2010), Rüstungskooperation 2.0: Notwendige Lehren aus dem A400M-Projekt (SWP-Aktuell No. 36), Berlin: Stiftung Wissenschaft und Politik.

Die Zeit (2010), “Meine Söhne fiebern mit”: Airbus-Chef Thomas Enders über kritische Stunden, zusätzliche Steuermilliarden für den Militärtransporter A400M - und warum es leichter ist, in China Fuß zu fassen, als in den USA', Die Zeit, March 11th, p. 24.

Edler, J., and A.D. James (2015), 'Understanding the emergence of new science and technology policies: policy entrepreneurship, agenda setting and the development of the European Framework Programme', Research Policy 44(6): $1252-1265$. 
Farrell, H. (2017), 'Thanks to Trump, Germany says it can't rely on the United States. What does that mean?', Washington Post. Retrieved 28 May 2017 from https://www.washingtonpost.com/news/monkey-cage/wp/2017/05/28/thanks-to-trumpgermany-says-it-cant-rely-on-america-what-does-that-mean/?noredirect=onandutm_term =.e3d1c3c901d8.

Farrell, H., and A. Newman (2016), 'The new interdependence approach: theoretical development and empirical demonstration', Review of International Political Economy 23(5): 713-736.

Faure, S.B.H. (2019), 'The choice for a minilateral Europe: a historical sociology of defence-industrial capitalism', European Review of International Studies 6(2): 92-114.

FAZ (2010a), 'Airbus droht mit Einstellung des Militärfliegers A400M: Die beteiligten Regierungen sollen mehr zahlen', FAZ, January 6th, p. 13.

FAZ (2010b), 'Wir haben die Produktion noch nicht im Griff: EADS-Chef Louis Gallois über Fehlkalkulationen beim Militärtransporter, Verzögerungen des A380 und das ökologisch korrekte Flugzeug', FAZ, January 17th, p. 31.

FAZ (2010c), 'A400M bleibt trotz Staatshilfe ein Verlustgeschäft', FAZ, March 8th, p. 17.

FAZ (2014), 'Schock im Bendlerblock', FAZ, October 5th, p. 2.

FAZ (2017a), 'Bundeswehr-Militärtransporter: Pannen beim A400M kosten Airbus Millionen', FAZ. Retrieved 9 February 2017 from https:/www.faz.net/aktuell/politik/inland/pannen-beim-a400m-kosten-airbus-millionen-14869827.html.

FAZ (2017b), 'Trump rüttelt europäische Rüstungshersteller durch', FAZ, February 16th, p. 17.

FAZ (2017c), 'Airbus hat Ärger mit Triebwerken', FAZ, July 28th, p. 27.

FAZ (2018a), 'Wie korrupt ist Airbus, Herr Enders?', FAZ, January 21st, p. 25.

FAZ (2018b), 'Airbus hebt an der Börse ab', FAZ, February 16th, p. 23.

FAZ (2018c), 'Bundeswehr und Nato-Partner vor massiven Transportproblemen', FAZ, April 21st, p. 2.

Financial Times (2015), 'Crash casts shadow over Airbus' military transport aircraft', Financial Times. Retrieved 11 May 2015 from https://www.ft.com/content/5ef43364-f7f0-11e4-962b-00144feab7d.

Financial Times (2017), 'Airbus chief shows military mettle for battles ahead: Ex-paratrooper Enders raises stakes amid troubled A400M programme’, Financial Times. Retrieved 2 March 2017 from https://www.ft.com/content/41a2e1ca-fafa-11e6bd4e-68d53499ed71.

Genschel, P., and B. Zangl (2014), 'State transformations in OECD countries', Annual Review of Political Science 17(1): 337-354.

George, A.L., and A. Bennett (2005), Case Studies and Theory Development in the Social Sciences, Cambridge, MA: MIT Press.

Gerring, J. (2007), Social Science Case Study Research: Principles and Practices, Cambridge: Cambridge University Press.

Giegerich, B. (2010), 'Budget crunch: implications for European defence', Survival 52(4): 87-98.

Hall, P.A., and D. Soskice (2001), 'An introduction to varieties of capitalism', in P.A. Hall and D.W. Soskice (eds.), Varieties of Capitalism: The Institutional Foundations of Comparative Advantage, Oxford, New York: Oxford University Press, pp. 1-68.

Hanrieder, T. (2016), 'Regionalization in the World Health Organization', in T. Rixen, L. Viola and M. Zürn (eds.), Historical Institutionalism and International Relations: Explaining Institutional Development in World Politics, Oxford, New York: Oxford University Press, pp. 96-119.

D.G. Hawkins, D.A. Lake, D.L. Nielson and M.J. Tierney (eds.) (2006), Political Economy of Institutions and Decisions. Delegation and Agency in International Organizations, Cambridge: Cambridge University Press.

Helmke, G., and S. Levitsky (2004), 'Informal institutions and comparative politics: a research agenda', Perspectives on Politics 2(4): 725-740.

Hepher, T., and S. Siebold (2010), 'Special report. The incredible saga of Europe's A400M', Reuters. Retrieved 8 June 2010 from https://www.reuters.com/article/us-air-a400m/special-report-the-incredible-saga-of-europes-a400m-idUSTRE6570NK20100 608.

Joana, J., and A. Smith (2006), 'Changing French military procurement policy: the state, industry and "Europe" in the case of the A400M', West European Politics 29(1): 70-89.

Keohane, R.O., and J.S. Nye (2011), Power and Interdependence, 4th edn., Boston: Longman.

Köhn, R. (2017), 'Plumpe Aktion', FAZ, October 6th, p. 22.

Koremenos, B., C. Lipson and D. Snidal (2001), 'The rational design of international institutions', International Organization 55(4): 761-799.

KPMG, P3 Group, and TaylorWessing (2014), Umfassende Bestandsaufnahme und Risikoanalyse zentraler Rüstungsprojekte: Exzerpt. Retrieved 30 September 2014 from https://www.bmvg.de/resource/blob/11644/ d5cdd057b87a9a9f84dadeaa72d4ae59/c-06-10-14-download-expertenbericht-zu-ruestungsprojekten-uebergeben-data.pdf.

Krotz, U. (2011), Flying Tiger. International Relations Theory and the Politics of Advanced Weapons, Oxford: Oxford University Press.

Kruck, A. (2016), 'Resilient blunderers: credit rating fiascos and rating agencies' institutionalized status as private authorities', Journal of European Public Policy 23(5): 753-770.

Kurc, C., and S. Oktay (2018), 'Taking production relations seriously: the role of defence firms in armaments cooperation', European Security 27(4): 469-489.

La Porta, R., F. Lopez-de-Silanes, A. Shleifer and R.W. Vishny (1998), 'Law and finance', Journal of Political Economy 106(6): 1113-1155. 
Lange, S. (2009), The End for the Airbus A400M? Repercussions and Alternatives for the German Military (SWP Comments No. 2), Berlin: Stiftung Wissenschaft und Politik.

Löwenstein, S., and C. Schubert (2010), 'Ein politisch-militärisch-industrieller Komplex. Das Ringen um den A400M steht vor der Entscheidung', FAZ, January 30th, p. 2.

Mahoney, J., and K. Thelen (2010), 'A theory of gradual institutional change', in J. Mahoney and K. Thelen (eds.), Explaining Institutional Change: Ambiguity, Agency, and Power, Cambridge: Cambridge University Press, pp. 1-37.

Markusen, A.R. (2003), 'The case against privatizing national security', Governance 16(4): 471-501.

Masseret, J.-P., and J. Gautier (2009), 'L'Airbus militaire A400M sur le "chemin critique" de l'Europe de la defense', Rapport D'information 205. Retrieved February 102009 from: https://www.senat.fr/notice-rapport/2008/r08-205-notice.html.

Mawdsley, J. (2013), 'The A400M project: from flagship project to warning for European defence cooperation', Defence Studies 13(1): 14-32.

Miller, G.J. (2005), 'The political evolution of principal-agent models', Annual Review of Political Science 8(1): $203-225$.

Moe, T.M. (2019), The Politics of Institutional Reform, Cambridge: Cambridge University Press.

Moravcsik, A. (1993), 'Armaments among allies: European Weapons collaboration, 1975-1985', in H.K. Jacobson, P.B. Evans and R.D. Putnam (eds.), Double-edged Diplomacy: International Bargaining and Domestic Politics, Berkeley: University of California Press, pp. 128-167.

Moravcsik, A. (1999), The Choice for Europe: Social Purpose and State Power from Messina to Maastricht, London: UCL Press.

New York Times (2009), 'Britain agrees to reopen talks over airbus A400M', New York Times. Retrieved July 252009 from https://www.nytimes.com/2009/07/25/business/global/25airbus.html.

OCCAR (2018), A400M Ministerial Meeting Communique. Retrieved January 262018 from https://www.occar.int/a400mministerial-meeting-communique?redirect=/programmes $/ \mathrm{a} 400 \mathrm{~m} \% 23$ news

Olsen, J.P. (2009), 'Change and continuity: an institutional approach to institutions of democratic government', European Political Science Review 1(1): 3-32.

Pierson, P. (2000), 'Increasing returns, path dependence, and the study of politics', American Political Science Review 94(2): 251-267.

Pierson, P. (2004), Politics in Time: History, Institutions, and Social Analysis, Princeton NJ: Princeton University Press.

Pollack, M.A. (1997), 'Delegation, agency, and agenda setting in the European Community', International Organization 51(1): 99-134.

Popa, M. (2018), 'What do good governments actually do? An analysis using European procurement data', European Political Science Review 10(3): 369-391.

Reuters (2018), 'Airbus will sich mit A400M-Käufern 2018 auf neuen Lieferplan einigen', Reuters. Retrieved February 82018 from https://de.reuters.com/article/europa-airbus-a400m-idDEKBN1FS0MU?il=0.

Rixen, T., and L.A. Viola (2014), 'Putting path dependence in its place: toward a Taxonomy of institutional change', Journal of Theoretical Politics 27(2): 301-323.

Scharpf, F.W. (1997), Games Real Actors Play: Actor-Centered Institutionalism in Policy Research, Boulder, Colorado: Westview Press.

Scherf, G. (2017), Authors' interview with former Director of Armaments Strategy, Defence Industrial Policy, and Cyber Security (German Ministry of Defense), June 12th, Frankfurt a.M., Berlin.

Schilde, K. (2017), The Political Economy of European Security, Cambridge: Cambridge University Press.

Schubert, C. (2018), 'Jubel bei Airbus', FAZ, February 16th, p. 26.

Schubert, C., and U. Friese (2017), 'Airbus verordnet Investitionsstopp wegen A400M', FAZ, October 6th, p. 22.

Seliger, M. (2017), 'Bloß keine Experimente. Die Bundesehr ist in einem miserablen Zustand', FAZ, August 4th, p. 28.

Senior Airbus official (2016), Authors' interview with senior Airbus official, November 22nd, Ottobrunn.

Shalal, A. (2018), Airbus upbeat on prospect for A400M export contract this year. Reuters. Retrieved 6 June 2018 from https://www.reuters.com/article/us-airbus-defence/airbus-upbeat-on-prospect-for-a $400 \mathrm{~m}$-export-contract-this-yearidUSKBN1JW1F1

Slayton, R. and A. Clark-Ginsberg (2018), 'Beyond regulatory capture: coproducing expertise for critical infrastructure protection', Regulation \& Governance 12(1): 115-130.

Streeck, W. (2010), E pluribus unum? Varieties and Commonalities of Capitalism (MPIfG Discussion Paper No. 10/12), Cologne: Max Planck Institute for the Study of Society.

Tallberg, J. (2002a), 'Delegation to supranational institutions: why, how, and with what consequences?', West European Politics 25(1): 23-46.

Tallberg, J. (2002b), 'Paths to compliance: enforcement, management, and the European Union', International Organization 56(3): 609-643.

Thelen, K. (2004), How Institutions Evolve, Cambridge: Cambridge University Press.

Thiem, A. (2011), 'Conditions of intergovernmental armaments cooperation in Western Europe, 1996-2006', European Political Science Review 3(1): 1-33.

UK Ministry of Defence (2018), Ministerial communiqué on the A400M programme. Retrieved 7 February 2018 from http:// www.defense-aerospace.com/article-view/release/190579/.html 
van der Heijden, J. (2010), 'A short history of studying incremental institutional change: does explaining institutional change provide any new explanations?', Regulation \& Governance 4(2): 230-243.

Wagner, W., A. Herranz-Surrallés, J. Kaarbo and F. Ostermann (2018), 'Party politics at the water's edge: contestation of military operations in Europe’, European Political Science Review 10(4): 537-563.

Weiss, M. (2014), 'Integrating the acquisition of Leviathan's swords? The emerging regulation of defense procurement within the EU', in P. Genschel and Jachtenfuchs M. (eds.), Beyond the Regulatory Polity? The European Integration of Core State Powers (1st ed.), Oxford: Oxford University Press, pp. 27-45.

Weiss, M. (2019), 'From wealth to power? The failure of layered reforms in India's defense sector', Journal of Global Security Studies 4(4): 560-578.

Weiss, M. (2020), 'Varieties of privatization: informal networks, trust and state control of the commanding heights', Review of International Political Economy 44(2): 1-28.

Weiss, M., and M. Blauberger (2016), 'Judicialized law-making and opportunistic enforcement: explaining the EU's challenge of national defence offsets', Journal of Common Market Studies 54(2): 444-462.

Weiss, M., and V. Jankauskas (2019), 'Securing cyberspace: how states design governance arrangements', Governance 32(2): 259-275.

Wiegel, M. (2017), 'Gemeinsam fliegen', FAZ, July 14th, p. 2.

Zürn, M. (1997), 'Assessing state preferences and explaining institutional choice: the case of Intra-German trade', International Studies Quarterly 41(2): 295-320.

Cite this article: Weiss M and Heinkelmann-Wild T (2020). Disarmed principals: institutional resilience and the nonenforcement of delegation. European Political Science Review 12, 409-425. https://doi.org/10.1017/S1755773920000181 